Marquette University

e-Publications@Marquette

College of Education Faculty Research and

Publications

Education, College of

$4-1-2015$

\title{
Theoretical Foundations of Learning Communities
}

Jody E. Jessup-Anger

Marquette University, jody.jessup-anger@marquette.edu

Accepted version. New Directions for Student Services, No. 149 (Spring 2015): 17-27. DOI. (C 2015

Wiley. Used with permission. 


\title{
Theoretical Foundations of Learning Communities
}

\author{
Jody Jessup-Anger \\ College of Education, Marquette University \\ Milwaukee, WI
}

This chapter describes the historical and contemporary theoretical underpinnings of learning communities and argues that there is a need for more complex models in conceptualizing and assessing their effectiveness.

Over the past half century, learning communities have evolved from an innovation adopted in isolation by postsecondary institutions to a wide-spread reform movement embraced by over 800 colleges and universities (Matthews, Smith, and MacGregor, 2012). Scholars describe a learning community as "an intentionally developed community that exists to promote and maximize the individual and shared learning of its members. There is ongoing interaction, interplay, and collaboration among the community's members as they strive for specified common learning goals" (Lenning, Hill, Saunders, Solan, and Stokes, 2013, p, 7). More specifically, learning communities arrange the curriculum to promote coherence in students' learning and increase intellectual interaction with faculty and peers (Gabelnick, MacGregor, Matthews, and Smith, 1990). The structure of a learning community can vary widely, from pairing courses from different disciplines with a common theme (for example, a sociology and psychology course on poverty) to more tightly coordinated studies that may encompass the entire educational experience during a given New Directions for Student Services, Vol. 2015, No. 149 Spring, 2015: pg. 17-27. DOI. This article is (c) Wiley and permission has been granted for this version to appear in e-Publications@Marquette. Wiley does not grant permission for this article to be further copied/distributed or hosted elsewhere without the express permission from Wiley. 
semester for both students and faculty (Matthews, Smith, MacGregor, and Gabelnick, 1997). Some learning communities incorporate a residential component into their design as well (Shapiro \& Levine, 1999).

The growth of learning communities is linked to broader reforms in undergraduate education that emerged as a result of concerns about the quality of undergraduate education detailed in reports by the Association of American Colleges (1985), the Boyer Commission on Educating Undergraduates in the Research University (1998), the Wingspread Group (1993) and the Association of American Colleges and Universities (AAC \& U) (2002). These reports raised concerns about undergraduate student learning and retention, as well as the content and coherence of the curriculum. More recently, the identification of learning communities as a research-based "high impact practice" (AAC \& U, 2007; Kuh, 2008) has bolstered interest in developing, sustaining, and assessing learning communities. Given the continuing interest in learning communities, this chapter provides an overview of their historical theoretical foundations, the research that undergirds their structure, and contemporary frameworks useful in conceptualizing and understanding their impact.

\section{Historic Theoretical Roots of Learning Communities}

As indicated in the previous chapter, most scholars credit educational theorists Alexander Meiklejohn and John Dewey (Gabelnick, MacGregor, Matthews, and Smith, 1990; Lenning and Ebbers, 1999) with providing the structural foundation of contemporary learning communities in the United States. Whereas contemporary educators laud Meiklejohn for his structural contribution to learning communities, they credit John Dewey with envisioning the pedagogical foundations, specifically "student-centered learning and active learning," two concepts espoused by contemporary learning community advocates (Gabelnick, MacGregor, Matthews, and Smith, 1990, p. 15). Dewey encouraged educators to ground the curriculum in students' experiences, cultivating students' individuality, advancing their interests, and promoting their construction of knowledge (Dewey, 1938). Although he was focused on the learning experience, Dewey New Directions for Student Services, Vol. 2015, No. 149 Spring, 2015: pg. 17-27. DOI. This article is (C) Wiley and permission has been granted for this version to appear in e-Publications@Marquette. Wiley does not grant permission for this article to be further copied/distributed or hosted elsewhere without the express permission from Wiley. 
stressed the importance of maintaining subject-matter at the center of education, emphasizing that content should drive the teaching method and arguing that the outcome of a successful educational experience is an expanded understanding of subject-matter coupled with an acknowledgement that there is more to know (Dewey, 1916). In a learning community environment, Dewey's ideas have been advanced by examining big questions and using differing disciplinary perspectives to illustrate the complexity of these questions, encouraging students to seek out further knowledge. Because Dewey's work focused more on primary and secondary schooling than on postsecondary education (Dewey, 1902; 1916; 1938), the application of his ideas in collegiate learning communities is fraught with difficulty, as one teacher is not the sole conductor of students' educational experiences. Rather, a learning community may include several instructors, academic advisors, and sometimes residence life staff or other administrators. These individuals may have varying levels of understanding of and commitment to the subject-matter of the course or courses, may not see the connections across disciplines, and tend to view one another with suspicion (Golde and Pribbenow, 2000). Thus, constant coordination and communication are critical to a successful learning community environment, which may explain in part why early learning communities were fleeting.

\section{Theoretical and Research Support for Learning Communities}

Since the mid-1980s, learning communities have flourished in a variety of postsecondary contexts. Student development theory and research support the aims and outcomes of these communities. Below are several theories and research studies that support the learning community structure. For a comprehensive overview of the cognitive theory that supports the learning community design, readers should refer to Powerful Learning Communities (Lenning, Hill, Saunders, Solan, and Stokes, 2013).

\section{Astin's involvement theory.}

Among the conditions of the college environment that Astin (1984) maintains are critical to student development is involvement, New Directions for Student Services, Vol. 2015, No. 149 Spring, 2015: pg. 17-27. DOI. This article is @ Wiley and permission has been granted for this version to appear in e-Publications@Marquette. Wiley does not grant permission for this article to be further copied/distributed or hosted elsewhere without the express permission from Wiley. 
which he defined as "the investment of physical and psychological energy in various objects" (p. 298). Astin argued that the amount of learning and development connected with an educational endeavor is proportional to the quality and quantity of student involvement in the experience and that some students will invest more energy than others in their educational activities. The structure of learning communities, with paired classes and intentional activities to foster faculty and peer interaction, is well suited to increase student involvement and thus enhance development.

\section{Tinto's departure theory.}

Vincent Tinto's (1993) work on student departure led to his interest in and research on the effectiveness of learning communities (Tinto, Goodsell Love, and Russo, 1994) in promoting student persistence. In his theory of individual departure, Tinto contends that students' decisions to leave a postsecondary institution stem from the interaction between their individual attributes (skills, prior educational experiences, and dispositions) and the academic and social systems of the institution (Tinto, 1993). He stressed the importance of academic and social integration into the institution, arguing that those students who choose to leave a postsecondary institution often do so because they are not academically or socially connected to the institution (Tinto, 1993). In research conducted at both two- and four-year institutions, Tinto and others found that students in learning communities form their own supportive peer groups which provide academic and social support, are more actively involved in classroom learning even after class, and ultimately learn more (Tinto, Goodsell Love, and Russo, 1994). Looking more specifically at living-learning communities, Wawrzynski, Jessup-Anger, Helman, Stolz, and Beaulieu (2009) had similar findings, namely that these communities produced a culture which promoted seamless learning, a scholarly environment, and an ethos of relatedness among faculty and peers.

\section{Interdisciplinary studies.}

Alexander Meiklejohn's belief in and promotion of interdisciplinary studies, coupled with his influence on the learning community movement via the Experimental College, in part explain

New Directions for Student Services, Vol. 2015, No. 149 Spring, 2015: pg. 17-27. DOI. This article is (c) Wiley and permission has been granted for this version to appear in e-Publications@Marquette. Wiley does not grant permission for this article to be further copied/distributed or hosted elsewhere without the express permission from Wiley. 
the influence of interdisciplinary studies on the learning community movement. Although there is variation in the definition, broadly speaking, interdisciplinary studies are defined as "a process of answering a question, solving a problem, or addressing a topic that is too broad or complex to be dealt with adequately by a single discipline or profession" (Klein and Newell, 1997). Often learning communities take an interdisciplinary approach in their curricular design, pairing students with two or more courses with similar topics from different disciplines. For example, among the offerings at Skagit Valley Community College in Mount Vernon, WA, is a learning community entitled Composing the American Diet, which pairs an English composition class and a nutrition class. The instructors of these classes agree to integrate their course topics and readings, discussing them from varying perspectives while also sharing assignments, readings, and activities. Although the interdisciplinary approach to a learning community requires faculty coordination and structural support, when it is done well, it can promote greater coherence and connectedness in the curriculum, ultimately improving student learning (Klein and Newell, 1997).

\section{Learning Communities as a High Impact Practice and other Relevant Research.}

In 2007, the AAC \& U identified learning communities as one of ten effective educational practices. Kuh (2008) used data from the National Study of Student Engagement to illustrate the strong positive effect of participating in a learning community and other high impact practices, noting that students who participated in these activities reported greater gains in learning and personal development. These findings echo those of other researchers (see Taylor, Moore, MacGregor, and Lindblad, 2003 for a comprehensive review) who demonstrated that overall, students who participate in learning communities have a richer academic experience; however, much of that richness is dependent on how the learning community is implemented. Lichtenstein (2005) found that the classroom environment plays an important role in the success of learning communities, with student outcomes varying greatly depending on the extent to which the classroom environment promoted linkages

New Directions for Student Services, Vol. 2015, No. 149 Spring, 2015: pg. 17-27. DOI. This article is (c) Wiley and permission has been granted for this version to appear in e-Publications@Marquette. Wiley does not grant permission for this article to be further copied/distributed or hosted elsewhere without the express permission from Wiley. 
between classes, communication between faculty, and used active learning methods and out of class group experiences.

Cox and Orehovec (2007) also noted tremendous variation across learning community environments. Using data from their study of faculty-student interactions in living-learning community environments, Cox and Orehovec developed a typology detailing interactions ranging from disengagement to mentoring, with incidental contact, functional interaction, and personal interaction defining the middle of the continuum. The authors argued that even in a learning community environment, which is marked by an expectation that faculty and students will interact outside of class, the greatest type of interaction is disengagement, as often faculty and students have little common ground on which to build a relationship. The authors suggested examining the cultural norms of the institution to determine the value placed on faculty-student interaction.

\section{On-line Learning Communities.}

As detailed in Calhoun and Santos Green's, Using Online Learning Communities in Student Affairs (chapter 6 of this volume), the emergence and rapid growth of online learning has raised questions about the possibility creating virtual communities that support the individual and shared learning of its members. Whereas in a traditional learning community, the structure is such that students are likely to be physically present with one another regardless of if they interact, in an online community, if students are not actively engaged, it is as though they are not in class at all (Palloff and Pratt, 2007). Garrison, Anderson, and Archer (2000) developed the Community of Inquiry Framework, a model of the necessary elements for the development of community and pursuit of inquiry in an online environment. Included in the model are three interacting core elements: a cognitive presence, social presence, and teaching presence. Cognitive presence addresses learners' construction and confirmation of meaning through reflection and discourse within the online community (Garrison and Anderson, 2003). Social presence addresses participants' ability to project themselves as 'real people' in the virtual community. Finally, teaching presence encompasses "instructional management, building understanding, and direct instruction" (Garrison, Anderson, and

New Directions for Student Services, Vol. 2015, No. 149 Spring, 2015: pg. 17-27. DOI. This article is (C) Wiley and permission has been granted for this version to appear in e-Publications@Marquette. Wiley does not grant permission for this article to be further copied/distributed or hosted elsewhere without the express permission from Wiley. 
Archer, 2000, p. 101). As one might expect, the elements necessary for a virtual community to flourish are similar to those in traditional learning communities.

The aforementioned studies illustrate that the mere presence of a learning community does not ensure positive learning outcomes, and attention needs to be paid to how learning communities are implemented. Wawrzynski and Jessup-Anger's (2010) longitudinal research on the effect of resource allocation to learning-community environments supports this claim. They found that the organizational structure of the environment affected students' academic experiences. Specifically, students who were in more comprehensively resourced communities - those with faculty affiliated directly with the community, classes or sections of classes geared to students in the community, and blended student and academic affairs roles within the community - reported significantly higher levels of academic peer interactions and perceived their environment as academically rich.

\section{Contemporary Frameworks for Conceptualizing and Assessing Learning Communities - Ecology theory}

As illustrated above, designing and assessing learning community environments is difficult because of the myriad different aspects to attend to, including instructor(s), students, content, pedagogy, and context. Consequently, sweeping generalizations about how to implement or assess a learning community that are not context bound may be counterproductive because they do not account for differences in students, instructors, or context. Although Meiklejohn and Dewey are helpful guides in understanding the history of learning communities, their contribution is anachronistic because it does not address the existence of a learning community in the context of today's complex postsecondary institution. New conceptual models are needed to guide the implementation and assessment of learning communities. In their comprehensive review of research related to college impact, Pascarella and Terenzini (2005) encouraged researchers and administrators to acknowledge the multitude of factors affecting student change, and to adopt broader conceptual models which might "more fully account for the multiple sources of

New Directions for Student Services, Vol. 2015, No. 149 Spring, 2015: pg. 17-27. DOI. This article is (C) Wiley and permission has been granted for this version to appear in e-Publications@Marquette. Wiley does not grant permission for this article to be further copied/distributed or hosted elsewhere without the express permission from Wiley. 
influence," instead of relying upon a single disciplinary perspective or dimension of students' experiences (p. 630).

Several human ecology researchers include the social contexts in which development occurs, which is helpful when conceptualizing or assessing learning communities. Influenced by Kurt Lewin's proposition that behavior is a function of a person and an environment (1936), two complementary human ecology models developed virtually simultaneously. The ecology of human development, which arose from Urie Bronfenbrenner's (1979) work exploring infant and adolescent development was one model, and Rudolph Moos's (1979) social ecology model, which examined the impact of the physical and social environment on human beings was another model.

\section{Bronfenbrenner.}

Bronfenbrenner (1979) emphasized the importance of studying human development in the context of "the actual environments, both immediate and remote, in which human beings live" (p. 12). His theory stressed the importance of considering development within the context it occurs, and specifically how biological factors - including physical characteristics and genetic propensities - interact with the "immediate environment, and the way in which this relation is mediated by forces emanating from more remote regions in the larger physical and social milieu" (Bronfenbrenner, 1979, pp. 12-13, italics in the original). Renn and Arnold (2003) encouraged researchers and administrators to consider Bronfenbrenner's model to gain a more holistic understanding of the learning environment, including the influence of peer culture. When considering the effectiveness of a learning community, the theory focuses one's gaze on students' experiences and the myriad environments that may shape their experiences, including formal and informal social and academic interactions, the broader university environment, and larger social structures affecting the student. Bronfenbrenner's model illustrates how personal attributes, called developmentally instigative characteristics, set in motion "reciprocal processes of interpersonal interaction" ( $p .12$ ) that affect learning. He outlined four types of these characteristics, including personal stimulus characteristics, selective responsivity, structuring proclivities, and directive beliefs. Perhaps

New Directions for Student Services, Vol. 2015, No. 149 Spring, 2015: pg. 17-27. DOI. This article is @ Wiley and permission has been granted for this version to appear in e-Publications@Marquette. Wiley does not grant permission for this article to be further copied/distributed or hosted elsewhere without the express permission from Wiley. 
most relevant to conceptualizing a learning community environment is Bronfenbrenner's (1993) first type, personal stimulus characteristics, which details how people's actions invite or inhibit particular responses from the environment that can disrupt or foster psychological growth (e.g., how peers might respond differently to a shy versus outgoing member of their learning community). Bronfenbrenner's second type, selective responsivity, describes how people interact with their surroundings (e.g., some students may immerse themselves fully in the learning community, attending activities outside of class and contributing regularly to discussion, while others might treat their learning community experience as they would any other class). The third type, structuring proclivities, details how people seek out increasingly complex activities (e.g., students may wrestle with disciplinary differences and ultimately integrate and cohere knowledge from two related courses). The fourth type, directive beliefs, refers to how people view their agency in relation to their environment (e.g., students who have a deep disciplinary grounding may feel more or less able to engage actively in the content of another discipline).

In a learning community, students possessing varying developmentally instigative characteristics interact with one another in addition to interacting with the faculty and student affairs administrators who are affiliated with the community. These interactions shape students' academic and social integration and ultimately affect their learning.

Another important aspect of Bronfenbrenner's (1993) model is the context, described as the environmental characteristics that interact with the person and affect developmental processes. Bronfenbrenner envisioned these characteristics as nested systems that surround an individual, from proximal to distal. He labeled these the micro-, meso-, exo-, and macrosystem.

Most relevant to understanding students' experiences in learning communities are microsystems because they include the student and learning community context. The microsystem is defined by Bronfenbrenner (1993) as "a pattern of activities, roles, and interpersonal relations" that are experienced in one's immediate environment that "invite, permit, or inhibit engagement" in that 
environment (p. 15). Within a learning community, there are aspects of students' microsystems that are identical, including their paired courses and co-curricular activities.

The mesosystem, defined as "a system of two or more settings frequented by the same person" (Bronfenbrenner, 1993, p. 20), details the linkages students may make to their shared microsystems (learning community), which may include their home, family, or peer group. While other elements of the context (exo-, and macrosystems) may affect students' developmental processes and experiences, they are more distal and do not contain the student.

Bronfenbrenner's model adds complexity to the way in which administrators and researchers conceptualize a learning community, encouraging them to consider not only what students bring to the community and their experiences within the community, but also the other factors that influence students' experiences, from financial aid policies to the ease of pairing courses through the registrar's office.

\section{Moos.}

Simultaneous to the emergence of the ecology of human development, social ecology, "the multidisciplinary study of the impact that physical and social environments have on human beings" arose out of Stanford University. Whereas the ecology of human development emphasized the interaction of direct and indirect environmental effects on biologically determined development (Bronfenbrenner, 1979), social ecology theory placed more emphasis on the immediate physical environment as a mediator of development, and underscored the importance of creating a physical and psychological environment that promotes effective human functioning (Moos and Insel, 1974). Consequently, Moos's work might be particularly useful when conceptualizing or assessing living-learning community environments because of their physical dimension.

Moos's (1979) model, "notes the existence of both environmental and personal systems, which influence each other through selection factors...[and] mediating processes of cognitive appraisal and activation or arousal (motivation)" (p. 4). These mediation processes typically arise when the environment necessitates New Directions for Student Services, Vol. 2015, No. 149 Spring, 2015: pg. 17-27. DOI. This article is @ Wiley and permission has been granted for this version to appear in e-Publications@Marquette. Wiley does not grant permission for this article to be further copied/distributed or hosted elsewhere without the express permission from Wiley. 
a response and result in efforts at adaptation and use of coping skills. The initiation of adaptation efforts may change both the environmental and the personal systems, and ultimately determines stability or change in student behavior.

The Environmental System. Moos (1979) described four major domains of variables within the environmental system, including "the physical setting, organizational factors, human aggregate, and social climate" (p. 6), each of which can potentially influence educational outcomes directly or indirectly through interaction with the other environmental variables. The physical setting includes the physical design and architecture of the environment. In a residential learning community, the physical setting may include the building in which the community is housed, the presence or lack of study and gathering spaces, and the amenities provided. Organizational factors include such dimensions as size of the learning community, paired classes, and offerings provided to students in the way of co-curricular activities. The human aggregate is comprised of the total characteristics of students in the setting, and may include "age, ability level, socioeconomic background, and educational attainment" (p. 8). Faculty and staff characteristics may also be part of the human aggregate. Moos found the human aggregate pertinent to the environmental system because of the "notion that most of the social and cultural environment is transmitted through other people," and the implication that "the character of an environment depends in part on the typical characteristics of its members" (p. 8). Also included in the human aggregate would be the collective attitudes of students, and their collective beliefs about the environment as promoting or thwarting their educational pursuits. The fourth domain, social climate, is inferred by the "continuity and consistency in otherwise discrete events" (p. 10). Within a learning community, the social climate would be the integrating features of the environment, including the students' overall attitudes toward each other and their beliefs about the role of peers in their learning. In addition to serving as a domain of the environmental setting, Moos viewed the social climate as a mediator of the other environmental variables.

New Directions for Student Services, Vol. 2015, No. 149 Spring, 2015: pg. 17-27. DOI. This article is @ Wiley and permission has been granted for this version to appear in e-Publications@Marquette. Wiley does not grant permission for this article to be further copied/distributed or hosted elsewhere without the express permission from Wiley. 
The Personal System. As might be expected, individual characteristics that assist in explaining students' responses to an environmental context comprise the personal system. "Background and personal indexes include age, sex, ability level, interests and values, ego strength and self-esteem, and preferences for such coping styles as active engagement in the environment, tension reduction and exploration" (Moos, 1979, p. 11). Other personal factors considered within the personal system include attitudes, expectations, and roles. Moos explained that "People who have more responsible organizational roles (such as administrators, professors, and teachers, as compared with high school and college students) tend to perceive educational settings more positively," and furthermore, "Expectations of new environments can influence both an individual's choice and later perception of an environment" (p. 11).

Mediating Factors. Moos (1979) identified two factors that mediate the interaction between the environmental system and the personal system, namely 1) Cognitive appraisal and 2) Activation or arousal. Cognitive appraisal is the process by which an individual evaluates the environment as "being either potentially harmful, beneficial, or irrelevant (primary appraisal) and his or her perception of the range of available coping alternatives (secondary appraisal)" (p. 11). Activation or arousal occurs when an individual appraises the environment as needing a response, which in turn "prompts efforts at adaptation, or coping, which may change the environmental system (students decide to use a recreation room as a library or study hall) or the personal system (students seek and obtain information that changes their attitudes or expectations)" (p. 12).

Coping and Adaptation. Moos (1979) explained that although situations chosen to study coping and adaptation usually involve major life changes including death, financial disaster, and serious illness, more common transitions and everyday situations also demand coping responses. Learning community outcomes, such as students' transition to college, persistence, development of cognitive complexity, and social and academic integration could be assessed through Moos's model because they illustrate how students cope with and adapt to their environment. Like Bronfenbrenner's (1979) model, Moos's model

New Directions for Student Services, Vol. 2015, No. 149 Spring, 2015: pg. 17-27. DOI. This article is (C) Wiley and permission has been granted for this version to appear in e-Publications@Marquette. Wiley does not grant permission for this article to be further copied/distributed or hosted elsewhere without the express permission from Wiley. 
encourages administrators and researchers to consider a variety of factors when designing and assessing learning communities. Unique to Moos's model is the emphasis on the physical environment, which is not often considered in learning community research and assessment and may help to unpack some of the tacit cultural messages that students within the community receive.

\section{Conclusion}

Having evolved from an innovation adopted to improve the quality of higher education, learning communities are now an integral part of many postsecondary institutions (Matthews, Smith, and MacGregor, 2012). As these communities become more commonplace, it is important not to lose sight of the theoretical underpinnings that guided their initial structure and function and the research that directs best practices in their implementation. In addition, as postsecondary institutions continue to increase in complexity, it is vital that administrators and scholars adopt more multifaceted models for conceptualizing and assessing these communities, acknowledging the myriad issues that affect their structure and the students within them.

\section{References}

Association of American Colleges. Integrity in the Curriculum: A Report to the Academic Community. Washington, DC, 1985.

Association of American Colleges \& Universities. Greater Expectations: A New Vision for Learning as a Nation Goes to College. Washington, DC, 2002.

Association of American Colleges and Universities. College Learning and the New Global Century. Washington, D. C. 2007.

Astin, A. W. "Student Involvement: A Developmental Theory for Higher Education." Journal of College Student Development, 1984, 25. 297308.

Boyer Commission on Educating Undergraduates in the Research University. Reinventing Undergraduate Education: A Blueprint for America's Research Universities. Stony Brook, NY: State University of New York at Stony Brook. 1998.

Bronfenbrenner, U. The Ecology of Human Development: Experiments by Nature and Design. Cambridge, MA: Harvard University, 1979.

New Directions for Student Services, Vol. 2015, No. 149 Spring, 2015: pg. 17-27. DOI. This article is (C) Wiley and permission has been granted for this version to appear in e-Publications@Marquette. Wiley does not grant permission for this article to be further copied/distributed or hosted elsewhere without the express permission from Wiley. 
NOT THE PUBLISHED VERSION; this is the author's final, peer-reviewed manuscript. The published version may be accessed by following the link in the citation at the bottom of the page.

Bronfenbrenner, U. "The Ecology of Cognitive Development: Research Models and Fugitive Findings." In R. H. Wozniak \& K. W. Fischer (eds.), Development in Context: Acting and Thinking in Specific Environments. Hillsdale, NJ: Erlbaum, 1993.

Cox, B. E., and Orehovec, E. "Faculty-Student Interaction Outside the Classroom: A Typology from a Residential College. The Review of Higher Education, 2007, 30, 343-362.

Dewey, J. "The Child \& the Curriculum." In R. D. Archambault (ed.), John Dewey on Education: Selected Writings. Chicago: University of Chicago, 1902.

Dewey, J. Democracy and Education. New York: Macmillan, 1916.

Dewey, J. Experience and Education. New York: Collier, 1938.

Gabelnick, F. MacGregor, J. Matthews, R. S., and Smith, B. L. (Eds). Learning Communities: Creating Connections among Students, Faculty, and Disciplines. New Directions for Teaching and Learning, no. 41. San Francisco: Jossey-Bass, 1990.

Garrison, D. R., \& Anderson. T. E-learning in the 21 $1^{\text {st }}$ Century: A Framework for research and Practice. New York: Routledge, 2003.

Garrison, D. R., Anderson, T., \& Archer, W. "Critical Inquiry in a Text-Based Environment: Computer Conferencing in Higher Education." The Internet and Higher Education, 2000, 2: 87-105.

Golde, C. M. and Pribbenow, D. A. "Understanding faculty involvement in residential learning communities." Journal of College Student Development, 2000, 41(1), 27-40.

Klein, J. T. and Newell, W. H. "Advancing Interdisciplinary Studies." In J. G. Gaff, J. L. Ratcliff, and Associates (Eds.), Handbook of the Undergraduate Curriculum. Washington, DC: Association of American Colleges \& Universities, 1997.

Kuh, G. D. High-Impact Educational Practices: What They Are, Who Has Access to Them, and Why They Matter. Washington, DC: Association of American Colleges \& Universities, 2008.

Lenning, O. T. and Ebbers, L. H. The Powerful Potential of Learning Communities: Improving Education for the Future. ASHE-ERIC Higher Education Reports, 26, 1999.

Lenning, O. T., Hill, D. M., Saunders, K. P., Solan, A, and Stokes, A. Powerful Learning Communities: A Guide to Developing Student, Faculty and Professional Learning Communities to Improve Student Success and Organizational Effectiveness. Sterling, VA: Stylus, 2013.

Lewin, K. Principals of Topological Psychology. New York: McGraw, 1936.

New Directions for Student Services, Vol. 2015, No. 149 Spring, 2015: pg. 17-27. DOI. This article is @ Wiley and permission has been granted for this version to appear in e-Publications@Marquette. Wiley does not grant permission for this article to be further copied/distributed or hosted elsewhere without the express permission from Wiley. 
NOT THE PUBLISHED VERSION; this is the author's final, peer-reviewed manuscript. The published version may be

accessed by following the link in the citation at the bottom of the page.

Lichtenstein, M. "The Importance of Classroom Environments in the Assessment of Learning Community Outcomes. Journal of College Student Development, 2005, 46(4), 341-356.

Matthews, R. S., Smith, B. L., and MacGregor, J. "The Evolution of Learning Communities: a Retrospective." In K. Buch and K. E. Barron (eds.), Discipline Centered Learning Communities. New Directions for Teaching and Learning, no. 132. San Francisco, CA: Jossey-Bass, 2012.

Matthews, R. S., Smith, B., L., MacGregor, J., and Gabelnick, F. "Creating Learning Communities." In J. G. Gaff, J. L. Ratcliff, and Associates (Eds.), Handbook of the Undergraduate Curriculum. Washington, DC: Association of American Colleges \& Universities, 1997.

Moos, R. H. Evaluating Educational Environments. San Francisco: JosseyBass, 1979.

Moos, R. H., and Insel, P. M. Issues in Social Ecology: Human Milieus. Palo Alto, CA: National Press Books, 1974.

Palloff, R. M., \& Pratt, K. Building Online Learning Communities: Effective Strategies for the Online Classroom ( $2^{\text {nd }}$ ed.). San Francisco: JosseyBass, 2007

Pascarella, E. T., and Terenzini, P. T. How College Affects Students. San Francisco: Jossey-Bass, 2005.

Renn, K. A., and Arnold, K. D. "Reconceptualizing Research on College Student Peer Culture." Journal of Higher Education, 2003, 74. 261291.

Shapiro, N. S., and Levine, J. H. Creating Learning Communities: A Practical Guide to Winning Support, Organizing for Change, and Implementing Programs. San Francisco: Jossey-Bass, 1999.

Taylor, K., Moore, W. S., MacGregor, J., and Lindblad, J. What We Know Now about Learning Community Research and Assessment. National Learning Communities Project Monograph Series. Olympia, WA: Washington Center

New Directions for Student Services, Vol. 2015, No. 149 Spring, 2015: pg. 17-27. DOI. This article is @ Wiley and permission has been granted for this version to appear in e-Publications@Marquette. Wiley does not grant permission for this article to be further copied/distributed or hosted elsewhere without the express permission from Wiley. 